\title{
Colchicine Induced Polyploidy in Chrysanthemum carinatum L.
}

Kalyan Singh Kushwah"1, Rakesh Chandra Verma ${ }^{2}$, Sapan Patel ${ }^{1}$ and NK Jain ${ }^{3}$

${ }^{1}$ School of Studies in Botany, Jiwaji University, Gwalior-474011, Madhya Pradesh, India

${ }^{2}$ School of Studies in Botany, Vikram University, Ujjain-456010, Madhya Pradesh, India

${ }^{3}$ Department of Botany, Govt. Holkar Science College, Indore-452001, Madhya Pradesh, India

*Corresponding author: Kalyan Singh Kushwah, School of Studies in Botany, Jiwaji University, Gwalior-474011, Madhya Pradesh, India, Tel: +918319167057, E-mail: kalyansinghkushwah85@gmail.com

Receiving date: Jan 10, 2018; Acceptance date: Feb 12, 2018; Publication date: Feb 19, 2018

Copyright: (c) 2017 Kushwah KS, et al. This is an open-access article distributed under the terms of the Creative Commons Attribution License, which permits unrestricted use, distribution, and reproduction in any medium, provided the original author and source are credited.

\begin{abstract}
Induction of colchitetraploidy was attempted in local Chrysanthemum carinatum $(2 n=18)$. The method used for colchicine treatment was "cotton swab method". The details about the successful induction of polyploidy, morphological features and cytological (meiosis) are described and compared with control characters. The phenotypic characters observed such as slightly slower growth, stronger stem, thicker and larger leaves, lager flowers and seeds in the colchitetraploid plant. Cytological characters also such as increase cell size, chiasma frequency, DNA contents and double chromosome number in colchitetraploid plant compared with control. The growth pattern, morphology, pollen stain-ability and seed set were recorded; however, main emphasis was given on chromosomes behavior of control and isolated colchitetraploidy.
\end{abstract}

Keywords: Chrysanthemum carinatum; Colchicine; Polyploidy; Meiosis

\section{Introduction}

Chrysanthemum carinatum $L$. the commonly known as 'Bijli' Malwa region of Madhya Pradesh in India. These are short days and long night's plants. The species of Chrysanthemum are herbaceous perennial plants growing to $100-150 \mathrm{~cm}$ tall, wall deeply lobed leaves and white large flower heads in species. The flower occurs in various forms, and can be daisy-like, decorative, pompons or buttons. This genus contains many hybrids and thousands of cultivars developed for horticultural purposes. In addition to the traditional yellow, other color are available, such as white, purple, and red. The most important hybrids is Chrysanthemum $\times$ morifolium (syn. C. $x$ grandiflorum), derived primarily from $\mathrm{C}$. indicum but also involving other species. Yellow or white Chrysanthemum flower are boiled to make a sweet drink in some parts of Asia. The resulting beverage is known simply as "Chrysanthemum tea", has many medicinal uses, including an aid in recovery from influenza. In Korea, a rice wine flavor with Chrysanthemum flower is called gukhwaju.

The effects of polyploidy on plant traits are also important to horticulturists and plants breeders. Polyploidy is one of the successful methods in the improvement of some plants such as apples (Tilney and Basset) Vicia faba [1], Phlox drummondii [2] etc. The process can occur naturally or through human manipulation. Polyploidy can also be induced through the use of chemical doubling agent's colchicine. Polyploidy induction can be used as a means to create and selective new and better breeds for the further use. The chemical colchicine is widely used because of its effectiveness, abundance and being nontoxic to cells. By producing polyploid Chrysanthemum carinatum, the production of better quality herbal substances from its extract will be possible and more economically feasible. Polyploidy can change morphological, phonological, physiological and ecological character of plants.
The overall objective of this research was to produce polyploid $C$. carinatum stock plants for future breeding and propagation program.

\section{Materials and Methods}

Colchicine treatment: Dry seeds (6.64\% moisture) of a variety of $C$. carinatum were sown in pots in the first week of November. The used in the present study were collected from the plants being maintained in the Botanical Garden of the Vikram University Ujjain (M.P.). Seedlings from each cross were germinated in seven separate pots with 25 seeds per pot. Healthy young potted plants of Chrysanthemum carinatum were selected for colchicine treatment to the seedlings region. Small cotton swabs soaked in aquaepus colchicine solution $(0.2 \%$ and $0.25 \%)$ were placed over apical meristem and solution added in drops at regular intervals for 3 days, with 6 hrs duration each day. Forty-eight seedlings were treated with $0.2 \%$ colchicne and eighty-nine seedlings treated with $0.25 \%$ colchicine.

Cytological study (Meiotic): Various morphological and other characters that changed due to induction of polyploidy were recorded as described earlier [3]. For meiotic analysis, young flower buds were fixed in $1: 3$ (acetic acid : absolute alcohol) mixture for $24 \mathrm{~h}$. The anthers of appropriate size were squashed in $2 \%$ iron-acetocarmine. Observations on meiotic chromosomes behavior were recorded from temporary slides. Pollen mother cells (PMCs) were analyzed for suitable stage of meiosis. Photographs were taken using temporary preparations with a Leica photographic microscope. The chromosomal characteristic of $C$. carinatum were not well defined, because these are ring, rod and 8-shaped. Figure 1 compares the metaphase, anaphase and prophase stages between the diploid and polyploid $C$. carinatum. Although the number of chromosomes could not be accurately counted, it was clearly visualized that the obtained plants were indeed polyploidy. Chromosomal association, chiasmata frequency, Anaphase distribution of chromosomes and other features were recorded. 


\section{Results}

The major aspect that has been undertaken in the present investigation is cytogenetic studies of Chrysanthemum carinatum. One hundred thirty seven Chrysanthemum carinatum plants treated with colchicine (HiMedia). In the treatment, cotton balls saturated with $0.2 \%$ (48 plants) and $0.25 \%$ (89 plants) colchocine were placed on seedling shoot tips. In the present investigation one polyploidy plant was obtained. The polyploidy plant exhibited superior phenotypes to those of diploids such as slightly slower growth, stronger stem, thicker and larger leaves, larger flowers and seeds. Colchicine solution of $0.2 \%$ was most effective means for the induction and showed only one polyploidy plant out of which twenty-nine colchicine treated survived plants (Table 1). Colchicine is arrested meiosis at diakinesis/ metaphase- 1 by disrupting spindle fiber formation. The colchitetraploid plant shows a larger number of genetic variants, affecting plant structure, flower morphology. Figure 2 (b) shows the growth in diameter and increase the number of petals. The average sizes of the controlled and treatment are found to be $2 \mathrm{~mm}$ and $3 \mathrm{~mm}$ respectively. This shows that the seed treated with the colchicine has increase by the $1 \mathrm{~mm}$. Figure 2 (d) show the growth length of the seeds.

The result of this study control plant showed nine bivalents chromosomes $(2 \mathrm{n}=2 \mathrm{x}=18)$ and polyploidy plant showed eighteen bivalent chromosomes $(2 \mathrm{n}=4 \mathrm{x}=36)$ at diakinesis/metaphase- $\mathrm{I}$ in all the 10 PMCs observed (Figure 1, pannels 1 and 2 control and 5-7 Polyploidy). Anaphase-I distribution of chromosomes were normal (9: 9) and polyploidy distribution of chromosomes (18:18) on each pole (Figure 1, pannels 3 and 4 control and 8 polyploidy).

In the present observation were comparisons of chiasma frequency with control and colchicine concentration. Ten PMCs. were analyzed at diakinesis/metaphase-I. The number of chiasma frequency per cell means from 4.1 out of which on average 13.6 were terminalized, giving terminalization coefficient of 0.30 and 5.8 were unterminalized chiasmata in normal (Table 2). The number of chiasma frequency per cell means from formula:

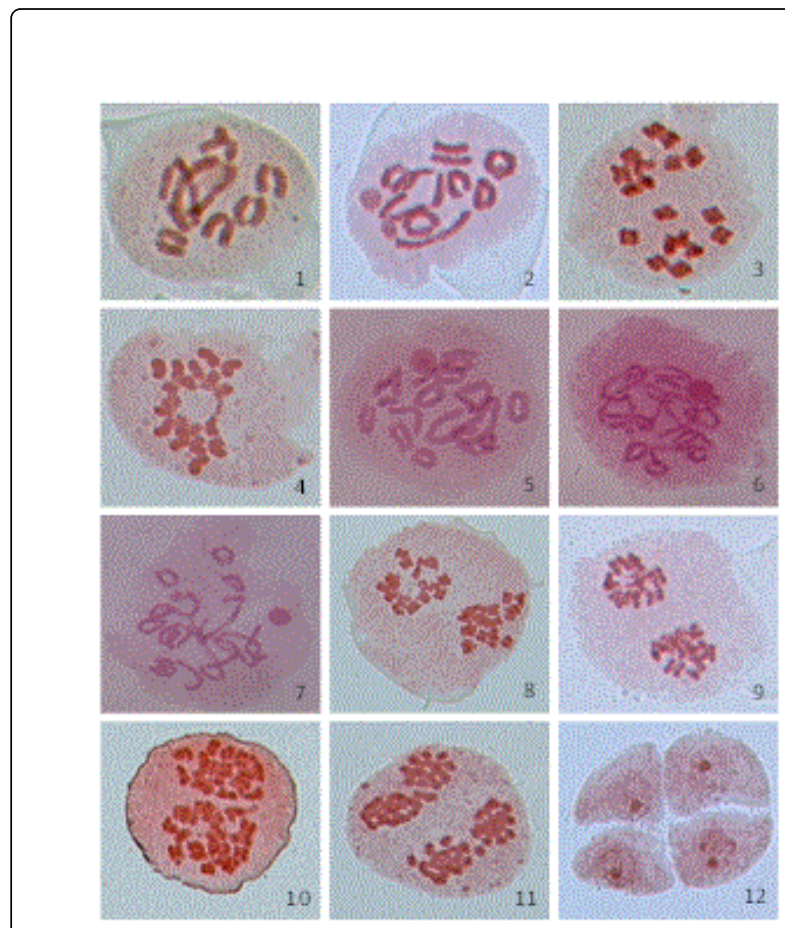

Figure 1: Meiotic stages in control and colchicine induced polyploidy: 1. Diakinesis/Metaphase-I and One Nucleolus 2. Diakinesis/Metaphase-I and two Nucleoli 3. Anaphase-I 4. Anaphase-I and Bridge formation of control 5. Diakinesis/ Metaphase-I and one Nucleolus 6. Diakinesis/Metaphase-I and two Nucleoli 7. Diakinesis/Metaphase-I and three Nucleoli 8. AnaphaseI 9. Telophase-I; 10. Anaphase-II 11. Telophase-II and 12. Tetrad of Polyploidy Chrysanthemum carinatum (L). (Arrowheads=Nucleolus).

\begin{tabular}{|c|c|c|c|c|c|c|c|}
\hline S. No. & $\begin{array}{l}\text { Colchicine } \\
\text { concentration (\%) }\end{array}$ & $\begin{array}{l}\text { No. of seeds } \\
\text { sowing }\end{array}$ & $\begin{array}{l}\text { No. of } \quad \text { seeds } \\
\text { germinated }\end{array}$ & $\begin{array}{l}\text { Total no. of } \\
\text { treated plants }\end{array}$ & $\begin{array}{l}\text { Total no. of } \\
\text { survived plants }\end{array}$ & $\begin{array}{l}\% \text { of Survived } \\
\text { plants }\end{array}$ & $\begin{array}{l}\% \text { of Obtained } \\
\text { polyploidy }\end{array}$ \\
\hline 1. & Control & 25 & 25 & -- & 25 & 100 & --- \\
\hline 2. & 0.2 & 50 & 48 & 48 & 29 & 60.41 & 2.08 \\
\hline 3. & 0.25 & 100 & 95 & 89 & 41 & 46.06 & Nil \\
\hline
\end{tabular}

Table 1: Polyploidy induction in C. carinatum by colchicines treatment.

\begin{tabular}{|c|c|c|c|c|c|c|c|c|}
\hline \multirow[t]{2}{*}{ Colchicine concentration } & \multirow{2}{*}{$\begin{array}{l}\text { No. of cells } \\
\text { analyzed }\end{array}$} & \multicolumn{3}{|l|}{ Chiasma } & \multicolumn{3}{|c|}{ Nucleolus (\%) } & \multirow{2}{*}{$\begin{array}{l}\text { Terminalization } \\
\text { coefficient }\end{array}$} \\
\hline & & Frequency/cell & $\begin{array}{l}\text { Termi- } \\
\text { nalization }\end{array}$ & $\begin{array}{l}\text { Untermi- } \\
\text { nalization }\end{array}$ & One & Two & Three & \\
\hline Control & 10 & 4.1 & 13.6 & 5.8 & 80 & 20 & -- & 0.30 \\
\hline 0.2 & 10 & 10.6 & 24.4 & 11.4 & 35 & 45 & 20 & 0.43 \\
\hline
\end{tabular}

Table 2: Chiasma frequency and Terminalization in C. carinatum at Diakinesis/Metaphase-I. 
Citation: Kushwah KS, Verma RC, Patel S, Jain NK (2018) Colchicine Induced Polyploidy in Chrysanthemum carinatum L.. J Phylogenetics Evol

\begin{tabular}{|c|c|c|c|c|c|c|c|c|c|c|c|}
\hline \multicolumn{12}{|c|}{ Diakinesis/Metaphase-I } \\
\hline \multirow[t]{2}{*}{ Material } & \multirow{2}{*}{$\begin{array}{l}\text { No. of cells } \\
\text { analyzed }\end{array}$} & \multicolumn{3}{|l|}{ Rod } & \multicolumn{3}{|c|}{ Ring } & \multicolumn{3}{|c|}{ 8-Shaped } & \multirow{2}{*}{$\begin{array}{l}\text { No. } \\
\text { bivalents }\end{array}$} \\
\hline & & No. & Mean & Range & No. & Mean & Range & No. & Mean & Range & \\
\hline Control & 10 & 44 & 4.4 & $3-7$ & 39 & 3.9 & $2-5$ & 7 & 0.7 & $0-2$ & 09 \\
\hline Treated & 10 & 76 & 7.6 & $5-12$ & 60 & 6.0 & $4-10$ & 26 & 2.6 & $1-5$ & 18 \\
\hline
\end{tabular}

Table 3: Frequency of rod, ring and 8-shaped chromosomes in polyploidy.

Formula:

$$
\text { 1. Chiasma frequency/Cell }=\frac{\text { Total No. of Chiasma in cell }}{\text { No. of Cells Observed }}
$$

2. Ternamilization coefficient $=\frac{\text { No. of Chiasma terminalized }}{\text { Total No. of Chiasma }}$

10.6 out of which on average 24.4 were terminalized, giving terminalization coefficient of 0.43 and 11.4 were unterminalized chiasmata in $0.2 \%$ colchicine concentration (Table 2 ). Different types of nucleolus were observed during meiotic diakenesis/metaphase-I in control and colchitetraploidy. Only 20\% PMCs had a complete two nucleolus and $80 \%$ PMCs had a complete one nucleolus in control (Table 2 and Figure 1, pannels 1 and 2). 35, 45 and 20\% PMCs had a complete one, two and three nucleolus in colchitetraploidy (Table 2 and Figure 1 pannels 5-7).

The number of bivalent chromosomes ring, rod and 8-shaped high frequency in colchicine concentration $0.2 \%$ compared with control. Its observed in ten PMCs. was analyzed at diakinesis/metaphase-I (Table 3).

\section{Discussion}

Polyploidy (having four completes sets of chromosomes) is relatively common in plants. By some estimates as many as $70 \%$ of all angiosperms are natural polyploids [4]. The results obtained show that the polyploidy induction uses of colchicine and polyploidy plant slightly slower growth, stronger stem and larger leaves, flower and
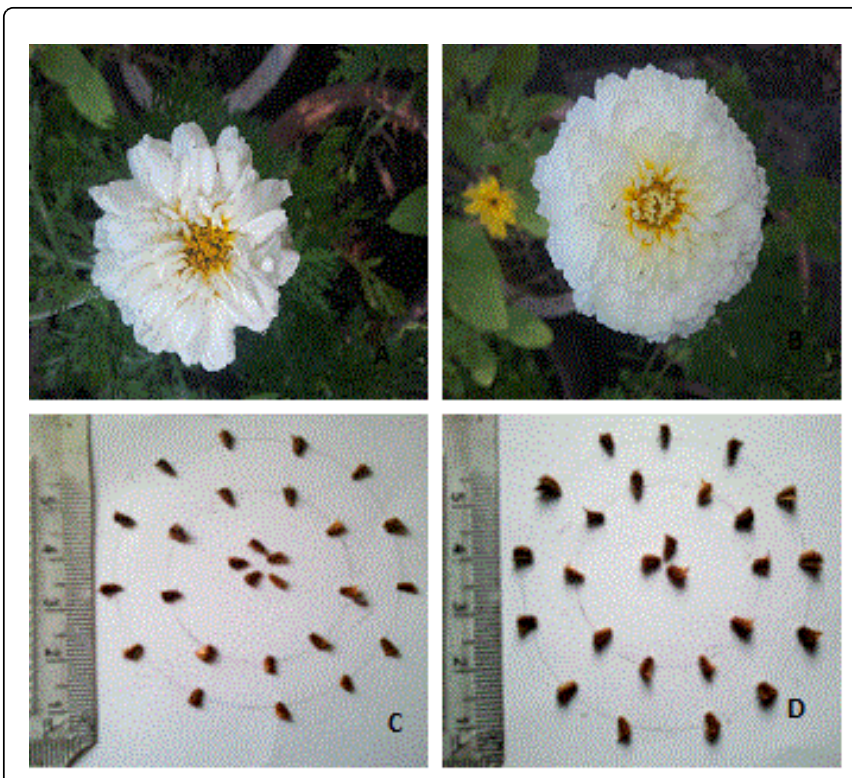

Figure 2: Phenotypes of control and polyploidy plants: A. Control flower B. Polyploidy flower C. Control seeds and D. Polyploidy seeds of Chrysanthemum carinatum (L).

seeds. Other effective, measures that indicate polyploidy include larger pollen size, greater number of chloroplasts per guard cell and stomata's. According to discussion polyploid induction has been used for plant breeding to produce bigger and more robust plants than diploid types [5] polyploids may also have additional desirable ornamental characteristic including thicker leaves and larger flowers with thicker petals that persist longer [6-9]. From many years it was observed that mutation causes alteration damage to plants 
chromosomes. This is because of using various chemical doubling mutagens.

In the present investigation one polyploidy plant were obtained. Induced polyploidy are not common type of chromosomes aberration in Chrysanthemum carinatum. Colchicine $(0.2 \%)$ saturated cotton balls were applied to the seedlings which could successfully induced polyploidy in Chrysanthemum carinatum. The chromosomes were counted as $36(2 \mathrm{n}=4 \mathrm{x}=36)$ in colchitetraploid and instead of 18 $(2 n=2 x=18)$ in control. Hence, there was doubling of chromosomes. Previously observation in many genera, different species will have different ploidy level (multiple of a base number) representing a series of polyploids. In the genus Chrysanthemum (syn. Dendranthema), different species have chromosome number of $2 \mathrm{n}=18,36,54,72,90$, and 198 - all multiples of a base chromosome numbers of 9 [10].

Confirmation of ploidy levels in treated seedling is essential to determine efficacy of these techniques. Although determination of ploidy level in Chrysanthum carinatum by counting chromosomes is possible, the chromosomes of Chrysanthum carinatum are small and particularly difficult to view and discern using traditional cytological techniques. Traditional cytology is often necessary to determine chromosomes number and ploidy level. This technique includes measurement on young leaves, root tips and anthers.

There are a number of factors that many provide polyploids with adaptive and evolutionary advantages. Perhaps most importantly, polyploidy can be significantly more heterozygous than their diploid counterparts. Polyploids can have four different genes (alleles) present at any given locus (location on a chromosome). The degree of heterozygosity may be a key factor in the growth, performance and adaptability of a polyploidy. Somatic doubling does not introduce any new genetic material, but rather produce additional copies of existing chromosomes. This extra DNA must be replicated with each cell division.

\section{Conclusion}

The results of this study demonstrate that method of applying a suspension of colchicine $0.2 \%$ in cotton swab to the shoots of Chrysanthum carinatum seedling is an effective method for inducing polyploidy. Although single applications resulted in polyploid plant developed in this study will be further evaluated for desirable traits and incorporated into an ongoing Chrysanthemum breeding program.

\section{References}

1. Joshi P, Verma RC (2004) High frequency production of colchicines induced autotetraploids in Faba bean ( Vicia faba). Cytologia 69: 141-147.

2. Verma RC, Ahirwar R, Das P (2011) Induction of polyploidy in Phlox drummondii by colchicine. J Cytol Genet 12: 1-5.

3. Chulaksananukul W, Chimnoi W (1999) Polyploid Induction in Centella asiatica (L.) urban by colchicine treatment. J Sci Res 24: 2 .

4. Masterson J (1994) Stomatal size in fossile plants: Evidence for polyploidy in majority of angiosperms. Science 264: 421-423.

5. Carvalho M de J da S de, Gomes VB, Souza A da S, Aud FF, Santos-Serejo $\mathrm{JA}$, et al. (2016) Inducing autotetraploids in cassava using oryzalin and colchicine and their in vitro morphophysiological effects. Genet Mol Res 15: 15028281.

6. Barlup J (2002) Letstalk hybridizing: Hybridizing with elepidote polyploid rhododendron. J Am Rhododendron Society 76: 75-77.

7. Hosoda T, Moriya A, Sarahima S (1953) Chromosome numbers of Satsuki, Rhododendron lateritium P1. Genetica 26: 407-409.

8. Kehr AE (1996) Polyploidy in rhododendron breeding. J Am Rhod Soc 50: $215-217$

9. Leach DG (1961) Rhododendron of the world and how to grow them Charles Scribners Sons, NY.

10. Ranney TG (2006) Polyploidy: From evolution to new plant development. Proc Intren Plant Propagators' Soc 56: 604-607. 